\title{
Correction to: Solving high-level Petri games
}

\author{
Manuel Gieseking ${ }^{1}$ (D) $\cdot$ Ernst-Rüdiger Olderog $^{1} \cdot$ Nick Würdemann $^{1}$ (D)
}

Published online: 8 July 2021

(C) The Author(s) 2021

\section{Correction to: Acta Informatica (2020) 57:591-626 https://doi.org/10.1007/s00236-020-00368-5}

The article "Solving high-level Petri games", written by Manuel Gieseking. Ernst-Rüdiger Olderog · Nick Würdemann was originally published electronically on the publisher's internet portal (currently SpringerLink) on March 09, 2021 without open access. The copyright of the article changed to (C) The Author (s) and this article is licensed under a Creative Commons Attribution 4.0 International License, which permits use, sharing, adaptation, distribution and reproduction in any medium or format, as long as you give appropriate credit to the original author(s) and the source, provide a link to the Creative Commons licence, and indicate if changes were made. The images or other third party material in this article are included in the article's Creative Commons licence, unless indicated otherwise in a credit line to the material. If material is not included in the article's Creative Commons licence and your intended use is not permitted by statutory regulation or exceeds the permitted use, you will need to obtain permission directly from the copyright holder. To view a copy of this licence, visit http://creativecommons.org/licenses/by/4.0/.

The original article has been updated.

Open Access This article is licensed under a Creative Commons Attribution 4.0 International License, which permits use, sharing, adaptation, distribution and reproduction in any medium or format, as long as you give appropriate credit to the original author(s) and the source, provide a link to the Creative Commons licence, and indicate if changes were made. The images or other third party material in this article are included in the article's Creative Commons licence, unless indicated otherwise in a credit line to the

The original article can be found online at https://doi.org/10.1007/s00236-020-00368-5.

Nick Würdemann

wuerdemann@informatik.uni-oldenburg.de

Manuel Gieseking

gieseking@informatik.uni-oldenburg.de

Ernst-Rüdiger Olderog

olderog@informatik.uni-oldenburg.de

1 Department of Computing Science, University of Oldenburg, Oldenburg, Germany 
material. If material is not included in the article's Creative Commons licence and your intended use is not permitted by statutory regulation or exceeds the permitted use, you will need to obtain permission directly from the copyright holder. To view a copy of this licence, visit http://creativecommons.org/licenses/by/4.0/.

Publisher's Note Springer Nature remains neutral with regard to jurisdictional claims in published maps and institutional affiliations. 